\title{
Postsplenectomy sepsis 10 years or more after operation
}

\author{
DIK EVANS \\ From the Department of Haematology, Royal Manchester Children's Hospital, Pendlebury, Manchester
}

SUMmaRy Three new cases (two fatal) of postsplenectomy sepsis occurring 14, 25, and 26 years after operation for hereditary spherocytosis are described. There are now 25 cases in the published work in which this complication occurred 10 or more years after operation, 14 of which were fatal. The mean age of onset is 37 years. The features of the disease are similar to those seen in other postsplenectomy infections, and pneumococcal infection was responsible in 19 cases (76\%). The major predisposing illnesses were trauma, hereditary spherocytosis, and idiopathic thrombocytopenia.

The risk of severe, sometimes fatal, infection after splenectomy is well recognised. ${ }^{-7}$ It seems to be more common in children, but occurs at all ages. The risk is greatest in the early months and years after operation. ${ }^{2}$ It may never disappear entirely, however, and one case occurring 45 years after operation has been described..$^{8}$ Several isolated case reports and small series have recorded late infections after splenectomy (Table 1), but this paper summarises the previous cases of postsplenectomy infection 10 or more years after operation. Three new cases are described, in which infection developed 14, 25, and 26 years after splenectomy; two of the patients died. The total number of reported cases of postsplenectomy infection 10 or more years after operation is now 25 .

\section{Case reports}

CASE 1

An 8 year old boy had his spleen removed for hereditary spherocytosis in 1951. Twenty six years later, aged 33, he was admitted to hospital with fever and malaise of sudden onset. He rapidly went cold and blue, lost consciousness, and died. A coroner's necropsy showed adrenal haemorrhage due to meningococcal septicaemia.

CASE 2

A 16 year old girl had an elective splenectomy for hereditary spherocytosis in 1964. Fourteen years later, aged 30, she developed a sudden illness with

Accepted for publication 8 November 1984 headache, purpura, and collapse. She had thrombocytopenia and afibrinogenaemia. The cerebrospinal fluid was heavily blood stained and grew pneumococci. She died the following day. The diagnosis was a consumption coagulopathy due to pneumococcal meningitis. No necropsy was performed.

\section{CASE 3}

A 4 year old girl underwent an elective splenectomy for hereditary spherocytosis. Twenty five years later she was admitted to hospital with pneumococcal meningitis. There were no complications and she made a full recovery.

\section{Discussion}

These three case histories summarise the features of post-splenectomy sepsis ${ }^{12}$ : there is a high rate of pneumococcal infectic. and a lower rate of meningococcal disease; dissemináad intravascular coagulation and adrenal haemorrhage are prominent complications; and fatal infection develops with dramatic suddenness.

All three patients reported here had hereditary spherocytosis; this is not coincidental. All were parents of children who attend haematology clinics at children's hospitals in Manchester. There are about 50 such families registered, and the children may attend with parents, grandparents, and other relatives. As the disease is inherited as an autosomal dominant disease, a large number of relatives have been seen, many of whom have had splenectomies.

Including these three cases, there are now 25 pub- 
Table 1 Patients with sepsis 10 or more years after splenectomy

\begin{tabular}{|c|c|c|c|c|c|c|c|}
\hline Sex & Age & Diagnosis & Organisms & $\begin{array}{l}\text { Years after } \\
\text { operation }\end{array}$ & Presentation & Outcome & Reference no \\
\hline $\begin{array}{l}\mathbf{F} \\
\mathbf{F} \\
\mathbf{M} \\
\mathbf{F} \\
\mathbf{F} \\
\mathbf{M} \\
\mathbf{F} \\
\mathbf{M} \\
\mathbf{M} \\
\mathbf{F}\end{array}$ & $\begin{array}{l}17 \\
34 \\
18 \\
32 \\
34 \\
36 \\
44 \\
47 \\
23 \\
43\end{array}$ & $\begin{array}{l}\text { Spherocytosis } \\
\text { ITP } \\
\text { ITP } \\
\text { Trauma } \\
\text { ITP } \\
\text { Trauma } \\
\text { Gastrectomy } \\
\text { Trauma } \\
\text { Trauma } \\
\text { Anaemia, cause } \\
\text { unknown }\end{array}$ & $\begin{array}{l}\text { Pneumococcus } \\
\text { Pneumococcus } \\
\text { Pneumococcus } \\
\text { Pneumococcus } \\
\text { Pneumococcus } \\
\text { H influenzae } \\
\text { Pneumococcus } \\
\text { Pneumococcus } \\
\text { Pneumococcus } \\
\text { Pneumococcus }\end{array}$ & $\begin{array}{l}14 \\
15 \\
10 \\
12 \\
15 \\
15 \\
10 \\
25 \\
10 \\
21\end{array}$ & $\begin{array}{l}\text { DIC } \\
\text { Endocarditis } \\
\text { DIC } \\
\text { DIC } \\
\text { DIC } \\
\text { Meningitis } \\
\text { DIC } \\
\text { DIC } \\
\text { DIC } \\
\text { Septicaemia }\end{array}$ & $\begin{array}{l}\text { Died } \\
\text { Survived } \\
\text { Died } \\
\text { Died } \\
\text { Died } \\
\text { Survived } \\
\text { Died } \\
\text { Died } \\
\text { Died } \\
\text { Died }\end{array}$ & $\begin{array}{r}9 \\
10 \\
10 \\
11 \\
12 \\
13 \\
14 \\
15 \\
16 \\
17\end{array}$ \\
\hline $\mathbf{M}$ & 27 & Trauma & Pneumococcus & 10 & $\begin{array}{l}\text { Adrenal } \\
\text { haemorrhage }\end{array}$ & Died & 18 \\
\hline $\begin{array}{l}\mathbf{F} \\
\mathbf{M} \\
\mathbf{M} \\
\mathbf{M} \\
\mathbf{M} \\
\mathbf{F} \\
\mathbf{F}\end{array}$ & $\begin{array}{l}47 \\
58 \\
51 \\
28 \\
33 \\
46 \\
49\end{array}$ & $\begin{array}{l}\text { Spherocytosis } \\
\text { ITP } \\
\text { Trauma } \\
\text { Trauma } \\
\text { Trauma } \\
\text { Trauma } \\
\text { SLE and } \\
\text { thrombocytopenia }\end{array}$ & $\begin{array}{l}\text { Meningococcus } \\
\text { Pneumococcus } \\
\text { Pneumococcus } \\
\text { Unidentified } \\
\text { Pneumococcus } \\
\text { Pneumococcus } \\
\text { Pneumococcus }\end{array}$ & $\begin{array}{l}10 \\
23 \\
45 \\
28 \\
13 \\
31 \\
25\end{array}$ & $\begin{array}{l}\text { Meningitis } \\
\text { Septicaemia } \\
\text { Septicaemia } \\
\text { Septicaemia } \\
\text { DIC } \\
\text { Septicaemia } \\
\text { Septicaemia }\end{array}$ & $\begin{array}{l}\text { Survived } \\
\text { Survived } \\
\text { Died } \\
\text { Survived } \\
\text { Died } \\
\text { Survived } \\
\text { Died }\end{array}$ & $\begin{array}{r}19 \\
20 \\
8 \\
21 \\
22 \\
22 \\
23\end{array}$ \\
\hline $\begin{array}{l}\mathbf{M} \\
\mathbf{M} \\
\mathrm{F} \\
\mathbf{M} \\
\mathbf{M}\end{array}$ & $\begin{array}{l}40 \\
42 \\
31 \\
44 \\
33\end{array}$ & $\begin{array}{l}\text { ITP } \\
\text { Trauma } \\
\text { Mononucleosis } \\
\text { Trauma } \\
\text { Spherocytosis }\end{array}$ & $\begin{array}{l}\text { Salmonella } \\
\text { Streptococcus } \\
\text { Pneumococcus } \\
\text { Pneumococcus } \\
\text { Meningococcus }\end{array}$ & $\begin{array}{l}11 \\
19 \\
11 \\
20 \\
26\end{array}$ & $\begin{array}{l}\text { Septicaemia } \\
\text { Septicaemia } \\
\text { Septicaemia } \\
\text { Meningitis } \\
\text { Septicaemia W-F } \\
\text { syndrome }\end{array}$ & $\begin{array}{l}\text { Survived } \\
\text { Survived } \\
\text { Survived } \\
\text { Survived } \\
\text { Died }\end{array}$ & $\begin{array}{l}23 \\
23 \\
23 \\
24 \\
\text { Present series }\end{array}$ \\
\hline $\begin{array}{l}F \\
F\end{array}$ & $\begin{array}{l}30 \\
29\end{array}$ & $\begin{array}{l}\text { Spherocytosis } \\
\text { Spherocytosis }\end{array}$ & $\begin{array}{l}\text { Pneumococcus } \\
\text { Pneumococcus }\end{array}$ & $\begin{array}{l}14 \\
25\end{array}$ & $\begin{array}{l}\text { Meningitis } \\
\text { Meningitis }\end{array}$ & $\begin{array}{l}\text { Died } \\
\text { Survived }\end{array}$ & $\begin{array}{l}\text { Present series } \\
\text { Present series }\end{array}$ \\
\hline
\end{tabular}

ITP = idiopathic thrombocytopenic purpura.

SLC $=$ systemic lupus erythematosus .

DIC = disseminated intravascular coagulation

WF syndrome $=$ Waterhouse-Friderichsen syndrome

${ }^{*}$ The organism was repeatedly isolated but proved unidentifiable.

lished cases of postsplenectomy sepsis developing 10 or more years after the operation. Thirteen were men and 12 were women; 14 died and 11 survived. In 18 cases $(72 \%)$ pneumococcus was implicated. Reasons for operation include trauma (11 cases), idiopathic thrombocytopenic purpura ( 5 cases), and hereditary spherocytosis (5 cases) (Table 1$)^{89-24}$

The deaths occurred suddenly in patients in early middle age; the mean age at infection was 37 years. None had been given any prophylactic treatment; indeed, the risk of infection in adults was not recognised until the late sixties, and in most cases the operation had been performed earlier. The risk is still not widely known, and what steps we should take to reduce the risk remain a matter for discussion. Furthermore, none of the adult patients seen with their children in the paediatric haematology clinics had ever been offered any prophylactic treatment, and none was aware of the risk of infection.

There are wide variations in the time at which patients are at risk (Table 2)..$^{2325-30}$ There is no doubt that the risk is maximal in the early years after operation, but the present data indicate that, for some patients, the risk never disappears entirely. However, only patients treated for trauma, haemolytic anaemia, and idiopathic thrombocytopenic purpura appear to be at risk. An analysis of all cases undergoing splenectomy in the North Western Regional Health Authority's hospitals between 1975 and 1982 showed that these diagnoses accounted for only $29 \%$ of splenectomies in a total of 2066 operations. Although malignant disease, cirrhosis, incidental splenectomy at gastrectomy, and other disorders account for most splenectomies, the poor survival rates from most of these disorders account for their absence in this list of long term post splenectomy sepsis.

Antipneumococcal and other vaccines ${ }^{3132}$ or penicillin $^{3}$ are being evaluated for prophylaxis. Their

Table 2 Time to sepsis after splenectomy

\begin{tabular}{lll}
\hline & & $\begin{array}{l}\text { Reference } \\
\text { number }\end{array}$ \\
\hline Majority within six years & Bisno and Freeman 1970 & 25 \\
80\% within four years & Eraklis and Filler 1972 & 26 \\
$75 \%$ within two years & Likhite 1976 & 27 \\
No difference & Ramsay and Bouskill 1976 28 \\
Majority within three years Walker 1976 & 29 \\
91\% within six weeks & Ein et al 1977 & 30 \\
Half within three years & Askergren and Björkholm & 23 \\
& 1980 & \\
\hline
\end{tabular}


value has not yet been established, and cases have been reported of fatal infections in patients with sickle cell disease (who are similarly predisposed to sepsis) after pneumococcal vaccine va $^{33}$ and in a splenectomised child given both pneumococcal vaccine and penicillin. ${ }^{35}$ It has not yet been established how often, if at all, pneumococcal vaccine needs to be given. At present the manufacturers recommend not less than five years between revaccination; earlier repeats risk unpleasant reactions. There is, however, a well established precedent for the lifelong use of penicillin for prophylaxis by patients at risk of rheumatic heart disease..$^{36}$ Lifelong penicillin prophylaxis could be extended to splenectomy patients. The present data suggest that long term prophylaxis is needed only for patients whose splenectomy is performed for trauma, congenital haemolytic anaemia, and idiopathic thrombocytopenic purpura. It does not seem likely, however, that patients would continue to take penicillin for many years or that physicians would prescribe it. Nor is it clear which doctor should be responsible. My investigations show that the risk persists and extend Ramsay's finding ${ }^{37}$ that in adults many cases of postsplenectomy sepsis occur more than five years after operation. Two or three years' postoperative penicillin is unlikely to be effective. Any pyrexia of undetermined origin in a splenectomised patient demands blood culture and treatment with ampicillin. ${ }^{37}$ Hospital junior staff, who have first contact with emergencies, must therefore be made aware of the problem. At the same time, we should advise our patients to wear a locket giving case details and guidance to treatment and give them a medical card indicating the diagnosis and clearly stating the risk of postsplenectomy sepsis and its management.

\section{References}

' Diamond LK. Splenectomy in childhood and the hazard of overwhelming infection. Pediatrics 1969;43:886-9.

${ }^{2}$ Singer DB. Post-splenectomy sepsis. In: Rosenberg HS, Bolande RP, eds. Perspectives in pediatric pathology Vol 1. Chicago: Book Medical Publishers Inc, 1973:285-311.

${ }^{3}$ Krivit W. Overwhelming post-splenectomy sepsis. Am J Hematol 1977;2:193-201.

4 Winkelstein JA. Splenectomy and infection. Arch Intern Med 1977;137:1516-7.

${ }^{5}$ Editorial. After splenectomy. Br Med J 1978;ii:1042-3.

- Ferguson A. Hazards of hyposplenism. Br Med J 1982;285:1275-6.

' Cooper MJ, Williamson RCN. Splenectomy: indications, hazards and alternatives. Br J Surg 1984;71:173-80.

${ }^{8}$ Buda JL, Arderin A, Gimimez J, Gomez-Acha JA. Kala azar of longstanding evolution in an asplenic patient. Trans $R$ Soc Trop Med Hyg 1979; 73:347-8.

${ }^{9}$ Ratnoff OD, Nebehay WG. Multiple coagulative defects in a patient with Waterhouse-Friderichsen syndrome. Ann Intern Med 1962;56:627-32.

10 Whitaker AN. Infection and the spleen: association between hyposplenism, pneumococcal sepsis and dissemina:ed intravascular coagulation. Med J Aust 1969;1:1213-9.

" Stossel TP, Levy R. Intravascular coagulation with pneumococcal bacteremia and symmetrical peripheral gangrene. Arch Int Med 1970;125:876-8.
12 Irsigler BG, Lubin A. Letter to the editor. Ann Intern Med 1970;73:140-1.

${ }^{13}$ Eykyn SJ, Thomas KD, Phillips I. Haemophilus influenza meningitis in adults. $\mathrm{Br}$ Med $J$ 1974; ii:463-5.

14 Rytel MW, Dee TH, Ferstenfeld JE. Possible pathogenetic role of capsular antigens in fulminant pneumococcal disease with disseminated intravascular coagulation (DIC). Am J Med 1974;57:889-96.

is Grinblat J, Gilboa Y. Overwhelming pneumococcal sepsis 25 years after splenectomy. Am J Med Soc 1975;270:523-4.

${ }^{16}$ Case reports of Massachusetts General Hospital: case 36-1975; N Engl J Med 1975;293:547-53.

${ }^{17}$ Lodewick PA. Fatal pneumococcal septicaemia with disseminated intravascular coagulation following splenectomy. J Med Soc N J 1975;72:730.

${ }^{18}$ Gopal V, Bisno AL. Fulminant pneumococcal infections in 'normal' asplenic hosts. Arch Intern Med 1977;137:1526-30.

${ }^{19}$ Langavecchia A, Frassoni G, Piovelli I. Common variable immune deficiency: long term clinical consequences of splenectomy in a case of late-onset hypogammaglobulinaemia Haematologica (Pavia) 1977; 63:326-32.

${ }^{20}$ Kingston ME, MacKenzie CR. The syndrome of pneumococcaemia, disseminated intravascular coagulation and asplenia. Can Med Assoc J 1979;121:57-61.

2" Archer GL, Coleman PM, Cole RM. Human infection from an unidentified erythrocyte-associated bacterium. $N$ Engl J Med 1979;301:897-900.

22 Ul-Haque A, Min KW, From P, Song J. Postsplenectomy pneumococcaemia in adults. Arch Pathol Lab Med 1980;104:258-60.

${ }^{23}$ Askergren J, Björkholm M. Postsplenectomy septicaemia in Hodgkin's disease and other disorders. Acta Chir Scand 1980; 146:569-75.

24 Tan KH. Fulminating pneumococcal septicaemia and meningitis in an adult twenty years after splenectomy for a ruptured spleen. Neth J Surg 1982;34:222-4.

${ }^{25}$ Bisno AL, Freeman JC. The syndrome of asplenia, pneumooccal sepsis, and disseminated intravascular coagulation. Ann Intern Med 1970;72:389-93.

${ }^{26}$ Eraklis AJ, Filler RM. Splenectomy in childhood: a review of 1413 cases. J Pediat Surg 1972; 7:382-8.

${ }^{27}$ Likhite VV. Immunological impairment and susceptibility to infection after splenectomy. JAMA 1976;236:1376-7.

${ }^{28}$ Ramsay LE, Bouskill KC. Fatal pneumococcal meningitis in adults following a splenectomy. Two case reports and a review of the literature. J R Nav Med Serv 1973;59:102-13.

${ }^{29}$ Walker W. Splenectomy in childhood: a review in England and Wales 1960-64. Br J Surg 1976;63:36-43.

${ }^{30}$ Ein SH, Shandling B, Simpson JS, et al. The morbidity and mortality of splenectomy in childhood. Ann Surg 1977;185:30710.

${ }^{31}$ Bisno AL. Hyposplenism and overwhelming pneumococcal infection; a re-appraisal. Am J Med Sci 1971;262:101-7.

32 Amman AJ. Current status of pneumococcal polysaccharide immunisation in patients with sickle cell disease or impaired splenic function. Am J Ped Hem/Oncol 1982;4:301-6.

${ }^{33}$ Ahonkhai VI, Landesman SH, Fikrig SM, et al. Failure of pneumococcal vaccine in children with sickle cell disease. $N$ Engl J Med 1979;301:25-7.

${ }^{34}$ Overturf GD, Field R, Edmonds R. Death from type 6 pneumococcal septicaemia in a vaccinated child with sickle cell disease. N Engl J Med 1979;300:143.

${ }^{3 s}$ Evans DIK. Fatal postsplenectomy sepsis despite prophylaxis with penicillin and pneumococcal vaccine. Lancet 1984;i: 1124.

${ }^{36}$ Kaplan EL, Bisno A, Derrick W, et al . AHA committee report: Prevention of rheumatic fever. Circulation 1977;55:1-4A.

${ }^{37}$ Ramsay LE. Infection in asplenic adults. $\mathrm{Br}$ Med J 1974;iii:254-5.

Requests for reprints to: Dr DIK Evans, Department of Haematology, Royal Manchester Children's Hospital, Pendlebury, Manchester M27 1HA, England. 